\title{
International attractiveness of undergraduate and postgraduate studies: is scientific production a determining factor?
}

\author{
Ana Blanco Mendialdua, Jon Barrutia Güenaga, Virginia Rincón Díez \\ Department of Financial Economics II, University of the Basque Country, Spain.
}

\begin{abstract}
The main objective of this research is to identify the influence of the scientific production of universities on their international demand. Specifically, we study whether the level of international demand, and the origin of this demand, is conditioned by the volume and quality of the scientific publications produced by Universities. In order to identify the influence of the volume of scientific production of the universities on their international demand, we have carried out various analyses of variance, using as a dependent variable the international demand and as an independent variable the volume of publications per professor and also the impact of these publications.

According to the results obtained, some international demand variables present significant differences depending on the number of scientific publications per university professor. Furthermore, these results show that there are no significant differences in the international attractiveness of postgraduate studies according to the impact of the scientific output of the universities. Given these results, we cannot conclude that the quality of scientific production of the Universities is a determining factor in attracting students from other countries. This first study points to a necessary reorientation of the requirements on university teaching staff if the international attractiveness of Spanish universities needs to be increased.
\end{abstract}

Keywords: Higher education, International, Postgraduate, Scientific production. 


\section{Introduction}

The current environment shows a decrease in the demand for university studies due to demographic evolution and, otherwise, an increase in the supply of postgraduate studies. Student mobility is greater and, as a consequence, the university market needs to be broaden to foreign students.

The international arena and, in particular, the European Higher Education Area-EHEA- is a reference for all institutions. The increase in the international attractiveness of higher education institutions is highlighted in the report on the Strategy for the Internationalization of Spanish Universities 2015-2020. In this report it is emphasized that "Universities must contribute to increasing Spain's attractiveness and competitiveness in a context of global competition for talent (students, professors, researchers, professionals, entrepreneurs)". Specifically, a strategic axis is defined as "increasing the international attractiveness of universities, improving the visibility and international recognition of university campuses as attractive environments".

The growing importance of scientific production in the University is well known in the teaching profession. Therefore, this requirement for scientific production is increased for teaching and research staff, and at the same time there is a need to deepen the knowledge of the international attractiveness of universities. Our focus is on how to relate these two factors. The data has been generated from the bibliographic records included in the data base of Scopus (owned by Elsevier B.V.), which currently contains more of 54 million documents with their Bibliographical references, from out of a total of about 30,000 Scientific journals from all fields. The amount of Scopus data doubles the number of Journals indexed with respect to the Web of Science (from Thomsom Reuters), which ensures a greater thematic and geographical coverage. It is absolute production, normalized impact, percentage of production in journals of the first quartile, for its impact and percentage of led documents that achieve scientific excellence.

The aim of this research is to identify the influence of the scientific production of universities on their international demand. Specifically, we study whether the level of international demand or the origin of this demand is conditioned by the volume or quality of the scientific publications of the universities. In short, the following research questions are intended to be answered.

- Does the volume of scientific production influence the international demand for higher education?

- Does the quality or impact of such scientific production affect the international demand for higher education?

Given the different nature of undergraduate and postgraduate studies, we have considered 
that the behavior of their demand may be conditioned by different factors, and we have therefore analyzed it in a differentiated manner.

The article is structured in five parts. After this introductory section, the theoretical framework is presented. In the third and fourth sections, the results of the analysis of international demand for undergraduate and postgraduate studies are presented. The last section contains the main conclusions of the study.

\section{Theoretical framework}

Analyzing the data bases referring to academic articles, it can be seen that there is a shortage of articles focused on the analysis of the attractiveness of Universities according to their scientific publication indicators. A starting point might be the capability of the University for attracting international researchers -not students-. This issue can be explained taking into account the combined influence of the factors of each country and the research orientation of university institutions (Lepori, Seeber and Bonaccorsi, 2015). There is also evidence that research orientation influences the creation of international networks (Seeber et al, 2012); and that the possibility of developing a research career in the destination country facilitates the recruitment of foreign researchers (Ivancheva and Gourova, 2011). Furthermore, the internationalization of researchers is also positively related to the internationalization of students, especially in the case of doctoral students (Horta, 2009). As for the attractiveness of universities to students, the added value of studying abroad over studying in the home country arises as a result of a combination of the attractiveness of the host country and the appropriateness of academic programs (Tarrant, Rubin and Stoner, 2014). Most studies indicate that a combination of the desire to travel and the opportunity to have a different experience (Lewellyn-Smith andMcCabe, 2008; Novak, Slatinsek and Devetak, 2013) with other factors such as the cost of living, language, even the climate of the destination country (Rodríguez González, Bustillo Mesanza and Mariel, 2011), or the student's previous mobility trajectory are factors that drive mobility.

In Spain, we can highlight the study carried out for the Catalan Universities (Rosello Villalonga, 2013). In addition to the quality of the teaching staff -measured on the basis of the level of inbreeding, the success rate of the current research sections on potential sections, percentage of doctoral professors and number of students per professor-, the author also analyses the influence of the quality of the students and the resources of the University (expenditure per student) on the choice of the destination University. The quality of students is measured by the grade point average, the average number of students enrolled, the rate of achievement (credits passed over credits enrolled), and the dedication of the student body enrolled. A promising result of this analysis indicates that students do take into account the quality of the faculty when choosing a university. 
Postgraduate studies in Spain are not yet as developed as in other European countries, due to the fact that incorporation into the EHEA has taken place later, and there is a lesser tradition of continuing to study once undergraduate studies have been completed. Besides, a change of trend is beginning to be observed in postgraduate studies: until now, universities have tried to differentiate themselves by offering a wider range of undergraduate degrees, but the search for differentiation in postgraduate studies is beginning to be observed, not by offering a greater diversity of postgraduate studies, but by seeking the specialization and quality of these studies. The main way to measure this quality is through research results (Pérez García and Serrano Martínez, 2012), highlighting articles published in reference journals or the achievement of competitive grants (Print and Hattie, 1997). In other words, two relevant variables appear here: scientific production (research results) and enrolment in postgraduate studies. For data relating to 2010 , both variables are positively related, but one variable explains little about the behavior of the other (Pérez García and Serrano Martínez, 2012, p. 183).

\section{International demand for undergraduate studies}

In this section, the effect of scientific production on the international demand for higher education is presented. The level of international demand is given by the number or percentage of international undergraduate students in the different universities and the origin of said demand by the number or percentage of students from different origins. The information on demand variables has been extracted from the Statistics on University Students of the Ministry of Education, Culture and Sport for the academic year 2014-2015. These statistics provide definitive data on students enrolled in Spanish universities.

With respect to scientific production, we have considered the volume of scientific publications from universities and the relative quality of these publications measured through impact indicators. All the data related to the publications of the Spanish universities have been collected from the Knowledge and Development Report 2014 prepared by the Knowledge and Development Foundation. In the fifth chapter of this report Corera, Chinchilla, De Moya and Sanz (2014) present the main research results of Spanish higher education institutions during the period 2009-2013. In order to reflect these results, these authors show both the total volume of scientific publications of the universities and their impact. Data on the scientific output of universities have been generated from the bibliographic records included in the Scopus database. Using this information in this paper, we have created two variables to classify universities according to their volume of scientific production and according to the quality of that scientific production.

Firstly, taking into account the number of documents published by each university during the 2009-2013 period, included in the Knowledge and Development Report 2014, and the total 
number of professors from each university, included in the Universities Personnel Statistics for the 2014-2015 academic year published by the Ministry of Education, Culture and Sport, we have calculated the volume of scientific production per professor of each institution. Considering this information, the variable built indicates if the volume of scientific production of a university is high or low depending on whether or not it exceeds the average of publications per professor of all universities.

On the other hand, to measure the quality of the research results of the universities we have considered the impact of their publications. Corera, Chinchilla, De Moya and Sanz (2014) in the aforementioned report present a normalized impact index for the different Spanish higher education institutions. This index tries to reflect the quality of the scientific production of the universities so that the institutions with a normalized impact in the world average have an index equal to 1 . This means that the works of this institution have been published in journals that are in the average impact of their category. Taking into account the normalized impact index, we have created a variable that distinguishes between universities with high and low impact scientific production according to whether this index is greater than 1 or not.

Through various analyses of the variance of one factor, the effect of the volume and quality of scientific production on the international demand of Spanish universities is studied in this paper. This technique is based on a contrast of equality of means and makes it possible to detect significant differences in the values of a dependent variable according to the categories of an independent variable. In the following paragraphs the main results obtained are presented.

\subsection{Volume of Scientific Production}

In order to identify the influence of the volume of scientific production of the universities on their international demand, we have carried out various analyses of variance using as a dependent variable some international demand variables and as an independent variable the volume of publications per professor. The total enrolment of the institutions according to their volume of scientific production has also been studied. According to the results obtained, it can be seen that some international demand variables present significant differences depending on the number of scientific publications perprofessor.

In the following table the mean values of the significant variables identified for both universities with a high volume of scientific production and those with a low volume of production are presented. 
Table 1. International Grade Demand by Scientific Output Volume (2014-2015)

\begin{tabular}{|c|c|c|c|c|c|c|}
\hline & \multicolumn{4}{|c|}{ SCIENTIFIC OUTPUT VOLUME } & \multirow[t]{3}{*}{ Global mean } & \multirow[t]{3}{*}{$\mathbf{F}$} \\
\hline & \multicolumn{2}{|c|}{ LOW } & \multicolumn{2}{|c|}{ HIGH } & & \\
\hline & $\mathbf{M}$ & SD & $\mathbf{M}$ & SD & & \\
\hline \multicolumn{7}{|l|}{$\begin{array}{l}\text { Level of the } \\
\text { international demand }\end{array}$} \\
\hline $\begin{array}{l}\text { International students } \\
(\%)\end{array}$ & 7.55 & 11.79 & 3.65 & 2.13 & 5.20 & $4.938 *$ \\
\hline International students & 323.97 & 464.86 & 904.60 & 914.07 & 673.83 & $10.655^{* *}$ \\
\hline \multicolumn{7}{|l|}{$\begin{array}{l}\text { Origin of the } \\
\text { international demand }\end{array}$} \\
\hline $\mathrm{EU}(\%)$ & 55.54 & 19.02 & 38.44 & 12.26 & 45.24 & $23.374 * * *$ \\
\hline Rest of Europe (\%) & 6.96 & 7.70 & 9.93 & 5.74 & 8.75 & 3.812 \\
\hline $\begin{array}{l}\text { United States and } \\
\text { Canada }(\%)\end{array}$ & 3.53 & 6.72 & 1.02 & 2.79 & 2.02 & $5.261^{*}$ \\
\hline Latin America (\%) & 22.37 & 15.39 & 26.34 & 12.20 & 24.77 & 1.601 \\
\hline Northern Africa (\%) & 3.55 & 5.34 & 10.72 & 8.71 & 7.87 & $16.769 * * *$ \\
\hline Rest of Africa (\%) & 3.25 & 4.73 & 3.71 & 3.17 & 3.53 & .265 \\
\hline Asia and Oceania (\%) & 4.79 & 5.21 & 9.84 & 8.11 & 7.83 & $9.446^{* *}$ \\
\hline \multicolumn{7}{|l|}{ Total enrolment } \\
\hline Total Enrolment & $5,797.71$ & $4,917.78$ & $25,190.47$ & $23,021.26$ & $17,483.09$ & $21.267 * * *$ \\
\hline
\end{tabular}

ANOVA's significance values: $* \mathrm{p}<.05 ; * * \mathrm{p}<.01 ; * * * \mathrm{p}<.001$

Regarding the level of international demand for undergraduate degrees, it can be seen that although the number of international students is higher in universities with a higher average volume of scientific production, the percentage of international students is significantly higher in universities with a lower volume of scientific publications per professor. Many of the universities with the highest scientific output are public and, as can be seen in the table above, their total enrolment is significantly higher.

Therefore, it can be said that universities less focused on scientific production, although they have fewer foreign students linked to their smaller size, in relative terms, seem to be more internationally attractive for undergraduate students. 
There are also differences in the origin of international demand between institutions with different volumes of scientific production. While the universities with the fewest publications appear to be geared towards students from the European Union, the United States and Canada, the most scientifically productive institutions focus on students from North Africa and Asia and Oceania.

\subsection{Quality of Scientific Production}

The effect of the quality of scientific production on international demand for grade has also been studied using various analyses of the variance of one factor. In each of these analyses, an international demand variable is used as a dependent variable and a variable reflecting the impact of university scientific publications is used as an independent factor or variable. In this way, the aim is to analyze the international demand of universities according to the quality of their scientific production. Quality is measured by the impact of publications, as it's said before by Corera, Chinchilla, De Moya and Sanz (2014), who present a standardized impact index for different higher education institutions. Institutions with normalized impact on the "world average" have an index equal to 1 . A variable is created to distinguish between universities with an index greater than 1 and universities with an index less than 1 .

Table 2 reflects the differences in international demand from universities according to the impact of their scientific publications.

The results reflect that, in relative terms, there are no significant differences in the level of international demand for degree from universities with scientific publications of different impact. Most universities with impact publications are public and total and international enrolment in these is higher. However, the percentage of international undergraduate students is not significantly different in universities with higher and lower impact research.

With respect to the origin of the international demand of the universities, there are differences depending on the quality of their scientific production. The institutions most focused on impact publications seem to be more oriented towards students from North Africa, Asia and Oceania as well as from European countries not participating in the European Union. Universities with less impact on their scientific publications, on the other hand, receive a higher percentage of international students from the European Union, the United States and Canada. 
Table 2. International demand of degree according to the impact of scientific production (2014-2015).

\begin{tabular}{|c|c|c|c|c|c|c|}
\hline & \multicolumn{4}{|c|}{ IMPACT OF SCIENTIFIC PRODUCTION } & \multirow[t]{3}{*}{ Global mean } & \multirow[t]{3}{*}{$\mathbf{F}$} \\
\hline & \multicolumn{2}{|c|}{ LOW } & \multicolumn{2}{|c|}{ HIGH } & & \\
\hline & $\mathbf{M}$ & SD & $\mathbf{M}$ & SD & & \\
\hline \multicolumn{7}{|l|}{$\begin{array}{l}\text { Level of the } \\
\text { international demand }\end{array}$} \\
\hline $\begin{array}{l}\text { International students } \\
(\%)\end{array}$ & 7.18 & 11.86 & 3.89 & 2.29 & 5.20 & 3.440 \\
\hline International students & 450.52 & 914.21 & 821.13 & 715.89 & 673.83 & $4.008 *$ \\
\hline \multicolumn{7}{|l|}{$\begin{array}{l}\text { Origin of the } \\
\text { international demand }\end{array}$} \\
\hline EU (\%) & 53.76 & 20.07 & 39.62 & 12.69 & 45.24 & $14.556 * * *$ \\
\hline Rest of Europe (\%) & 6.78 & 7.14 & 10.05 & 6.14 & 8.75 & $4.657^{*}$ \\
\hline $\begin{array}{l}\text { United States and } \\
\text { Canada }(\%)\end{array}$ & 3.48 & 6.74 & 1.05 & 2.79 & 2.02 & $4.850^{*}$ \\
\hline Latin America (\%) & 24.50 & 15.77 & 24.94 & 12.14 & 24.77 & .019 \\
\hline Northern Africa (\%) & 3.26 & 4.85 & 10.91 & 8.72 & 7.87 & $19.782 * * *$ \\
\hline Rest of Africa (\%) & 3.52 & 4.68 & 3.53 & 3.23 & 3.53 & .000 \\
\hline Asia and Oceania (\%) & 4.71 & 5.23 & 9.90 & 8.07 & 7.83 & $9.999 * *$ \\
\hline \multicolumn{7}{|l|}{ Total enrolment } \\
\hline \multirow[t]{2}{*}{ Total Enrolment } & $11,195.0$ & $26,733.0$ & $21,630.5$ & $13,717.3$ & $17,483.0$ & $5.137 *$ \\
\hline & 3 & 3 & 3 & 9 & 9 & \\
\hline
\end{tabular}

ANOVA's significance values: $* \mathrm{p}<.05 ; * * \mathrm{p}<.01 ; * * * \mathrm{p}<.001$

\section{International demand for Postgraduate Studies}

In this section the international demand for postgraduate studies from universities according to the volume and quality of their scientific publications is analyzed. As in the previous section, the information on the level and origin of the international demand for postgraduate studies has been obtained from the Statistics on University Students of the Ministry of Education, Culture and Sport for the academic year 2014-2015. 
In each of these analyses, we have used as a dependent variable some international postgraduate demand variable and as an independent variable or factor a variable that reflects the volume of scientific production of the universities or the quality of said production. In the following lines we show the main results obtained.

\subsection{Volume of Scientific Production}

As indicated above, we intend to study the international demand for postgraduate studies according to the volume of scientific publications of the universities. The objective is to determine whether or not there are differences in the foreign demand for postgraduate studies of universities according to the average number of publications per professor. In the following table we present the international demand for postgraduate studies of universities with different volumes of scientific production.

Table 3. International postgraduate demand according to the volume of scientific production (2014-2015)

\begin{tabular}{|c|c|c|c|c|c|c|}
\hline & \multicolumn{4}{|c|}{ SCIENTIFIC OUTPUT VOLUME } & \multirow[t]{3}{*}{ Global mean } & \multirow[t]{3}{*}{$\mathbf{F}$} \\
\hline & \multicolumn{2}{|c|}{ LOW } & \multicolumn{2}{|c|}{ HIGH } & & \\
\hline & $\mathbf{M}$ & SD & $\mathbf{M}$ & SD & & \\
\hline \multicolumn{7}{|l|}{$\begin{array}{c}\text { Level of the international } \\
\text { demand }\end{array}$} \\
\hline International students (\%) & 18.57 & 14.75 & 15.18 & 9.86 & 16.58 & 1.522 \\
\hline International students & 300.58 & 470.38 & 342.32 & 327.47 & 325.10 & .219 \\
\hline \multicolumn{7}{|l|}{$\begin{array}{c}\text { Origin of the international } \\
\text { demand }\end{array}$} \\
\hline $\mathrm{EU}(\%)$ & 24.57 & 20.07 & 24.19 & 11.00 & 24.35 & .012 \\
\hline Rest of Europe (\%) & 4.27 & 5.23 & 5.13 & 3.57 & 4.77 & .768 \\
\hline United States \& Canada (\%) & 2.75 & 4.38 & 2.37 & 2.07 & 2.53 & .267 \\
\hline Latin America (\%) & 57.05 & 26.34 & 48.46 & 15.63 & 52.00 & 3.338 \\
\hline Northern Africa (\%) & 1.59 & 3.32 & 3.81 & 4.22 & 2.90 & $6.354 *$ \\
\hline Rest of Africa (\%) & 1.32 & 2.37 & 2.31 & 2.65 & 1.90 & 2.972 \\
\hline Asia and Oceania (\%) & 8.12 & 10.38 & 13.73 & 12.21 & 11.41 & $4.613^{*}$ \\
\hline \multicolumn{7}{|l|}{ Total enrolment } \\
\hline Total Enrolment & $1,249.15$ & $1,259.36$ & $2,140.51$ & $1,568.37$ & $1,772.83$ & $7.331 * *$ \\
\hline
\end{tabular}


In the case of the international demand for postgraduate studies, the differences between universities with higher and lower volumes of scientific production decrease considerably. The behavior of international demand for postgraduate studies is similar for both types of universities. According to the results obtained, there are only significant differences in the students from North Africa and from Asia and Oceania, whose importance is greater in the universities with the highest volume of publications per professor.

\subsection{Quality of Scientific Production}

We have also analyzed the international demand for postgraduate studies from universities according to the quality of their publications. In this case, the objective is to analyze the differences in international demand for postgraduate studies depending on whether the universities have a higher or lower impact scientific output. The following table reflects the average values in the variables of international postgraduate demand both in universities with high-impact publications and in universities with low- impact publications.

The results of the analysis show that there are no significant differences in the international attractiveness of postgraduate studies according to the impact of the scientific output of the universities. Taking the percentage of foreign students as an indicator of the capacity to attract international postgraduate students, it can be said that this capacity is practically identical in universities with scientific publications of different impact.

The origin of the international demand for postgraduate studies, on the other hand, is different according to the quality of scientific production. Institutions less focused on high-impact scientific publications seem to be more oriented towards Latin American students. However, universities with high quality research have a higher percentage of postgraduate students from North Africa and Asia and Oceania.

\section{Conclusions}

The situation in Spanish universities shows us postgraduate studies with a higher rate of mobility than undergraduate studies. In addition, the postgraduate course offers are more specialized, seeking differentiation via quality measured according to the scientific production of teaching and research staff.

We cannot conclude that the scientific production of the Universities nor the quality of it is a determining factor in attracting students from other countries. In the case of undergraduate students, it even seems that international students go to universities with less research orientation and a greater focus on teaching. 
Table 4. International postgraduate demand according to the impact of scientific production (2014-2015)

\begin{tabular}{|c|c|c|c|c|c|c|}
\hline \multicolumn{5}{|c|}{ IMPACT OF SCIENTIFIC PRODUCTION } & \multirow{3}{*}{$\begin{array}{c}\text { Global } \\
\text { mean }\end{array}$} & \multirow[t]{3}{*}{$\mathbf{F}$} \\
\hline & \multicolumn{2}{|c|}{ LOW } & \multicolumn{2}{|c|}{ HIGH } & & \\
\hline & $\mathbf{M}$ & SD & $\mathbf{M}$ & SD & & \\
\hline \multicolumn{7}{|l|}{$\begin{array}{c}\text { Level of the international } \\
\text { demand }\end{array}$} \\
\hline International students (\%) & 16.95 & 13.42 & 16.31 & 11.31 & 16.58 & .053 \\
\hline International students & 295.91 & 455.48 & 345.60 & 341.36 & 325.10 & .311 \\
\hline \multicolumn{7}{|l|}{$\begin{array}{c}\text { Origin of the international } \\
\text { demand }\end{array}$} \\
\hline $\mathrm{EU}(\%)$ & 24.47 & 20.53 & 24.26 & 10.39 & 24.35 & .003 \\
\hline Rest of Europe (\%) & 3.81 & 5.34 & 5.45 & 3.34 & 4.77 & 2.841 \\
\hline United States \& Canada (\%) & 2.71 & 4.30 & 2.40 & 2.19 & 2.53 & .187 \\
\hline Latin America (\%) & 60.43 & 24.81 & 46.08 & 15.60 & 52.00 & $10.071 * *$ \\
\hline Northern Africa (\%) & .84 & 1.46 & 4.34 & 4.57 & 2.90 & $17.936^{* * * *}$ \\
\hline Rest of Africa (\%) & 1.25 & 2.43 & 2.36 & 2.59 & 1.90 & 3.753 \\
\hline Asia and Oceania (\%) & 6.10 & 9.80 & 15.14 & 11.67 & 11.41 & $13.251 * * *$ \\
\hline \multicolumn{7}{|l|}{ Total enrolment } \\
\hline Total Enrolment & $1,587.18$ & $1,835.75$ & $1,903.17$ & $1,229.44$ & $1,772.83$ & .851 \\
\hline
\end{tabular}

We are aware that more in-depth statistical analysis is needed, but this first study points to a necessary reorientation of the requirements on university teaching staff if the international attractiveness of Spanish universities is to be increased. Perhaps scientific articles should be more widely disseminated or extended to a wider audience, rather than often remaining within the university itself. Re-awarding quality teaching, without neglecting research, can be an important factor if national universities aspire to place themselves on the international map. This aspect becomes more visible in public universities, since in theory they should attract a higher percentage of foreign students because they have a higher scientific production and of higher quality than private ones. However, our results do not corroborate this appreciation. 
Finally, we must not forget the projection of universities in society. Perhaps we should go further and talk about the University-Society relationship in a much more globalized environment than is currently contemplated.

\section{References}

Corera, E., Chinchilla, Z., De Moya, F. and Sanz, L. (2014): "Indicadores de producción científica de las universidades españolas y las instituciones de investigación". Informe Conocimiento y Desarrollo 2014, Fundación Conocimiento y Desarrollo.

Gobierno de España, Ministerio de Educación, Cultura y Deporte, (2014). Estrategia para la internacionalización de las universidades españolas 2015 - 2020.

Horta, H., (2009). Global and national prominent universities: internationalization, competitiveness and the role of the State. Higher education, 58 (3), 387-405.

Ivancheva, L., Gourova, E., (2011). Challenges for career and mobility of researchers in Europe. Science and Public Policy 38 (3), 185-198.

Lepori, B., Seeber, M., Bonaccorsi, A., (2015). Competition for talent. Country and organizational-level effects in the internationalization of European higher education institutions. Research Policy (44), 789-802.

Lewellyn_Smith, C., McCabe, V.S., (2008). What is the attraction for exchange students: the host destination or host University? Empirical evidence from a study of an Australian University. International Journal of Tourism Research, 18 (6), 593-607.

Novak, R., Slatinsek, A., Devetak, G., (2013). Importance of motivating factors for international mobility of students Empirical Findings on Selected Higher Education Institutions in Europe. Organizacija, 46 (6), 274-280.

Pérez García, F., Serrano Martínez, L. (Dirs.), (2012). Universidad, universitarios y productividad en España. Fundación BBVA.

Print, M., Hattie, J., (1997). Measuring quality in universities: an approach to weighting research productivity. Higher education, 33 (4), 453-469.

Rodríguez González, C., Bustillo Mesanza, R., Mariel, P., (2011). The determinants of international student mobility flows: an empirical study on the Erasmus programme. Higher Education, 62 (4), 413-430.

Roselló Villalonga, J., (2013). ¿Importa la calidad de las Universidades en la elección de los estudiantes?.Hacienda Pública Española / Review of Public Economics, 207 (4/2013), 41-70.

Seeber, M., Lepori, B., Lomi, A., Aguillo, I., Barberio, V., 2012. Factors affecting weblink connections between European higher education institutions. Journal of Info- metrics 6 (3), 435-447.

Tarrant, M.A., Rubin, D.L., Stoner, L. (2014). The added value of study abroad fostering a global citizen. Journal of Studies in International Education, 18 (2), 141-161. 